DOI 10.18551/rjoas.2021-12.06

\title{
THE STUDY OF SHARING ECONOMY PLATFORM IN INDONESIA: ETHICAL PERCEPTIONS AS MEDIATOR
}

\author{
Syamsoeyadi Hidayat ${ }^{\star}$, Tjokrosaputro Miharni \\ Master's Program of Management Faculty, University of Tarumanagara, Jakarta, Indonesia \\ *E-mail: hidayat.117201029@stu.untar.ac.id
}

\begin{abstract}
This study aims to obtain the quantitative results related to the effect of electronic word of mouth (e-WOM) towards value co-creation on sharing economy platform in Indonesia with ethical perceptions as the mediator. The sampling technique that was used is non-probability sampling of 223 respondents all around Indonesia that was collected using questionnaires with online survey. The data was analyzed used Partial Least Square-Structural Equation Modeling. The results of this study indicate that ethical perceptions have positive and significant effect in mediating the role of electronic word of mouth towards value co-creation on sharing economy platform in Indonesia. This study also gives insight about the priority of ethical perceptions above electronic of mouth as the step of consideration for company to make decision in improving the value of corporation.
\end{abstract}

\section{KEY WORDS}

Ethical perceptions, sharing economy platform, electronic word of mouth (e-WOM), value cocreation.

Indonesia is the largest country in Southeast Asia which has the 4th largest population of the world that is population of $275,122,131$ people (Gov, 2021). With such a large population, the need for mobility is even higher, especially in big cities which are the drivers of economic growth in Indonesia. However, along with the development of technology, congestion on the highway becomes unavoidable so that smart solutions are needed to address these problems. The existence of sharing economy platform has answered this need in Indonesia. With the presence of Go-Jek platform for the first time in 2010 (Go-Jek, 2021) which was then followed by Grab until now have become very popular ride sharing platform in Indonesia. It could be said that development of the sharing economy platform in Indonesia is very rapid. Even the sharing economy platform in Indonesia has status as decacorn whose valuation is more than 10 billion US dollars (Aksara, 2021).

In the development of the sharing economy platform, ethical issues become important because they relate to people's trust in using the application. In this case, the ethical issues include issues of data security, privacy, shared value, fulfillment/reliability, and service recovery (Nadeem et al., 2019). Compared to the time when sharing economy platform didn't exist, people were afraid to use the services because they didn't know who the drivers due to the safety of driving. For this reason, the issue of ethical perception is very crucial for companies to run the sharing economy platform.

The process involved in the sharing economy platform is a process that runs between service providers and consumers who use the services. Meanwhile, the company only acts as a platform provider to bridge these two needs. This means that the company of platform provider does not have to own vehicles to be able to make activities on the sharing economy platform. This process is called value co-creation on sharing economy platform. The company only acts as bridge between service providers and consumers. Purchase decisions are not the main goal of the platform provider company but rather value co-creation (Gronroos et al., 2015).

The role of digital marketing is important to encourage the process of value co-creation in sharing economy platform (Diges \& Debasa, 2020). The quantitative research that explains about this relationship is still very limited especially about sharing economy platform in Indonesia. So, to fill this gap, this paper will present one of the main points in digital 
marketing that can encourage the process of value co-creation namely electronic word of mouth (e-WOM). So, it could be said that e-WOM is one of driving factor that can increase the activities of value co-creation in sharing economy platform. Within the background stated above, we can see that this study aims to see the relationship between ethical perceptions, e-WOM, and value co-creation of sharing economy platform in Indonesia.

\section{THEORETICAL REVIEW}

This section will explain about the definition of sharing economy platform, ethical perceptions, electronic word of mouth and value co-creation then the previous research about relationship between the variables are presented. The last part of the section will explain about the hypotheses of this research.

Sharing economy platform. Belk (2014) defined sharing economy platform as acquisition or distribution of a resource coordinated by people for a fee or other type of compensation. Stephany (2015) explained that "The sharing economy is the value in taking underutilized assets and making them accessible online to a community, leading to a reduced need for ownership of those assets.". So, it could be said that sharing economy platform is where one party provides goods/services to another in exchange for a certain amount of money. Sharing economy is not a new concept; it has existed as part of society's dynamics since ancient times. We used the barter system to address societal requirements before the concept of money was introduced. With today's technological developments, the concept of barter has evolved into the term "sharing economy platform." In addition, the sharing economy includes things like access to a service without the need for ownership, peer-to-peer services, using resources that have not been used for a long time. With this sharing economy concept, unused assets become valuable by facilitating online access within a community.

Ethical perceptions. In marketing, ethical perception could be defined as the systematic study of how moral standards are applied in marketing, behavioural and corporate decisions (Lazniak \& Murphy, 2019). It can be shown that the ethical part of marketing refers to company moral standards as well as ethical characteristics in specific scenarios. Consumers can perform online transactions with ease thanks to the existence of moral norms in the sharing economy platform. Nadeem et al. (2019) said that there are 5 dimensions in ethical perceptions that affects transaction activity in sharing economy platform namely privacy, security, shared value, fulfilment/reliability and service recovery. Besides that, there was another dimension in ethical perceptions that was examined by Nadeem et al. but didn't have the effect in the process namely non-deception.

Electronic Word of Mouth (e-WOM). Wu \& Wang (2011) said that e-WOM is the knowledge exchange that consumers carry out online. As a result, e-WOM might be defined in this study as information about the good or bad of a product or service that is disseminated over the internet or social media so that people can decide if the product or service is useful or not. People who have never used the product or service can get the information or expertise they need through this e-WOM before deciding to utilize it.

Value co-creation. According to Vargo et al. (2008), value co-creation could be defined as service science, which is the integration of existing resources in service systems and resources in other service systems under certain conditions that are beneficial for the welfare of all parties. Value co-creation, as defined in this study, is a two-way value creation process in which service providers and consumers collaborate to give value to the sharing economy platform. The role of customers in maintaining, using, enhancing, and adjusting the service provider's services to the particular situation, behaviour, and demands of these consumers makes the process more efficient.

Previous research. There is a variety of literature that discusses the e-WOM variable, ethical perceptions and value co-creation that can be used as a reference in compiling the research. In examining the relationship between consumer participation in shared value creation with ethical perceptions as a mediating variable, Nadeem et al. (2019) conducted a study of 453 respondents using the CB-SEM (Covariance-Based Structural Equation 
Modeling) methodology. The consumer participation variable includes 3 dimensions, namely information participation, follow-up participation and attitude participation. While ethical perceptions include the dimensions of privacy, security, fulfilment, value sharing and service recovery. The results show that consumer participation has a positive effect on ethical perceptions and also on the creation of shared value.

Nadeem and Al-Imamy (2020) also conducted research on the effect of ethical perceptions on value creation along with the quality of the relationship as a mediator. By using the SEM method and the number of respondents 348 people, the results show that ethical perceptions have no significant effect on value co-creation in the sharing economy. On the other hand, relationship quality has a positive effect on value co-creation and also strongly mediates between ethical perceptions and value co-creation. In this study, the observed ethical perception variable has 5 dimensions as in previous studies (privacy, security, fulfilment, shared value and service recovery), while relationship quality includes dimensions of commitment, trust and satisfaction.

In addition to researching consumer participation, Nadeem et al. (2020a) also examines the effect of social support (emotional support and informational support) on value co-creation along with ethical perceptions and relationship quality as mediations. The study, which involved 342 respondents using the SEM method, showed that social support had a positive effect on ethical perceptions and also had an effect on value co-creation. In addition, ethical perceptions also affect the quality of relationships in the sharing economy platform. In contrast to ethical perceptions, it turns out that trust and commitment (on the relationship quality variable) have no effect on value co-creation.

Kunja and GVRK (2018) investigated the effect of e-WOM on purchasing decisions with the creation of shared value as a mediation. The study took 762 respondents with analysis using the SEM method. The results of this study indicate that e-WOM has a significant effect on purchase intention which is also significantly mediated by value cocreation. On the other hand, value co-creation also influences purchase intention of consumers.

Research by Alimamy and Nadeem (2021) which took 266 respondents using the SEM method showed that authentic experience had no significant effect on value co-creation, but with ethical perceptions and customer involvement as mediation, the results had a significant effect.

In a study conducted by Saa'it et al. (2016) using the Multiple Regression Analysis method (the number of respondents was 361 people), the effect of e-WOM on purchase intention was investigated. The e-WOM variables here include relevance, accuracy, timeliness and completeness. The results of this study indicate that e-WOM has significant effect on purchase intention.

By involving 165 respondents, Mikalef et al. (2017) examined the effect of socialization variables, personal recommendations, product selection, and availability of information on purchase intention and Word of Mouth (WOM) using the PLS-SEM method. The results of this study indicate that socialization, personal recommendations and product selection have significant influence on purchase intention and WOM. Meanwhile, the information availability variable does not have a significant effect on purchasing decisions and WOM. The results of this study also indicate that purchase intention has a positive influence on WOM.

Martinez-Gonzalez et al. (2021) conducted research on value variables, external variables (e-WOM, information quality, and reputation), trust and internal variables (satisfaction, social norms, and consumer behaviour) on consumer participation. Using the PLS SEM methodology and the number of respondents 532, the results show that the value variable affects e-WOM, e-WOM has a positive effect on information quality, information quality affects reputation, reputation affects consumer trust, consumer trust affects social norms, social norms affect consumer behaviour and behaviour consumers influence consumer participation in the sharing economy.

Research on e-WOM variable which includes the quality of e-WOM, credibility of eWOM, and quantity of e-WOM on purchase intention with company image as a mediation was studied by Bataineh (2015) using the multiple regression analysis method (number of 
respondents 1000) showing the results that e-WOM in quality, credibility, and quantity have a significant and positive effect on purchase intention. Corporate image also mediates and strengthens the relationship between the independent variable and the dependent variable.

Sumi \& Tjokrosaputro (2020) examines the relationship between consumer participation and ethical perceptions of value co-creation on Grab Bike platform in Indonesia. By using the PLS method with 200 respondents, the results show that consumer participation and ethical perceptions have a significant effect on value co-creation.

From the explanation that mentioned above, we can see that the literature which explains about the relationship between e-WOM towards ethical perceptions still inadequate. Most of the studies discussed about the relationship between e-WOM and purchase intention and customer participation. However, the relationship between e-WOM towards value cocreation can be seen there which is said that e-WOM has significant effect towards purchase intention with value co-creation as mediating variable (Kunja \& GVRK, 2018). It is also showed that ethical perceptions has positive and significant effect towards value co-creation both as direct and indirect effect (mediating variable). So, this paper will show the relationship between ethical perceptions, e-WOM and value co-creation in sharing economy platform especially in Indonesia.

Based on this background with the relationship between the variables, the hypotheses are constructed below and can be seen in Figure 1:

$\mathrm{H}_{1}$ : Electronic word of mouth (e-WOM) has positive effect toward ethical perceptions of sharing economy platform users.

$\mathrm{H}_{2}$ : Ethical perceptions have positive effect toward value co-creation of sharing economy platform users.

$\mathrm{H}_{3}$ : Electronic word of mouth has positive effect toward value co-creation of sharing economy platform users.

$\mathrm{H}_{4}$ : Ethical perceptions play the role in mediating e-WOM and value co-creation of sharing economy platform users.

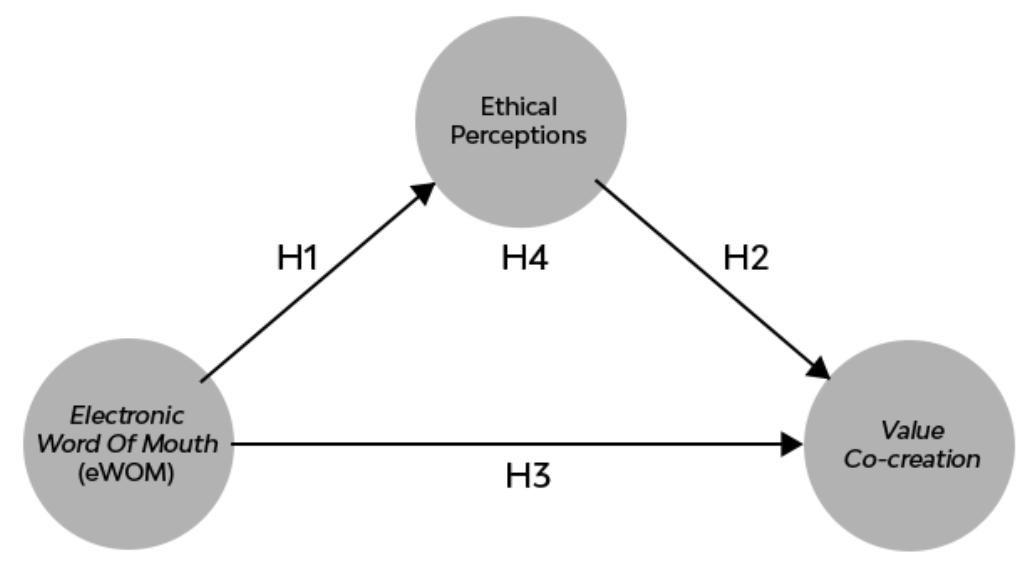

Figure 1 - Research Conceptual Framework

\section{METHODS OF RESEARCH}

In this research, non-sampling technique was applied by using questionnaire (online survey) to collect the data. The subject of this research was people that used sharing economy platform in the last 3 months. People who filled the survey have the age from 18 years above and spread in big islands in Indonesia (Java, Sumatera, Sulawesi, Kalimantan, Bali \& Nusa Tenggara, and Maluku \& Papua Islands). The scale that used in this survey was Likert scale 1-5 where scale 1 was "very disagree" statement and scale 5 was "very agree" statement. There were 269 respondents that filled the survey form. But after doing the screening, only 223 respondents complete the answers. The detail of respondents can be seen in Table 1. Partial Least Square - Structural Equation Modeling (PLS-SEM) is applied 
to process the result (Reinartz et al., 2009) by using SmartPLS 3.3.3 software. The indicators that were used of each variable as operationalization can be seen in Table 2.

Table 1 - Sample Profiles

\begin{tabular}{llll}
\hline Gender & \multicolumn{3}{l}{} \\
\hline Male & $53,4 \%$ & Female & $46,6 \%$ \\
\hline Age & \multicolumn{4}{l}{} \\
\hline $18-22$ years & $6.3 \%$ & $41-55$ years & $6.3 \%$ \\
$23-29$ years & $26.5 \%$ & above 55 years & $3.6 \%$ \\
$30-40$ years & $57.4 \%$ & & \\
\hline Occupation & \multicolumn{4}{l}{} \\
\hline Student & $6.7 \%$ & Entrepreneur & $28.7 \%$ \\
Employee & $49.8 \%$ & Other & $14.8 \%$ \\
\hline
\end{tabular}

Source: Data Processed Results (2021).

\section{RESULTS AND DISCUSSION}

Based on loading results shown in Table 2 for each indicator, E-WOM 2 doesn't show the correlation with the construction of measurement model because its loading factor is below 0,6. So, the test was re-run without using indicator E-WOM 2. After doing the test again, the reliability and validity test were passed by all indicators. For complete validity and reliability of measures can be seen on Table 3.

Table 2 - Measurement and Indicators of Each Variable

\begin{tabular}{|c|c|c|c|}
\hline \multicolumn{2}{|c|}{ Construct \& Indicator Items } & Mean & SD \\
\hline \multicolumn{4}{|c|}{ Electronic Word of Mouth } \\
\hline E-WOM 1 & The contact lists on my social media are mostly trustworthy. & 3.753 & 0.931 \\
\hline E-WOM 3 & $\begin{array}{l}\text { The ride sharing application is popular because of the large number of } 0.802 \\
\text { comments/reviews by users on the application. }\end{array}$ & 3.655 & 1.117 \\
\hline E-WOM 4 & $\begin{array}{l}\text { I became more interested in using the ride sharing application after I read } 0.810 \\
\text { the comments/reviews made by consumers }\end{array}$ & 3.480 & 1.194 \\
\hline E-WOM 5 & In the future, I will use the app as my first choice. & 3.435 & 1.086 \\
\hline \multicolumn{4}{|c|}{ Ethical Perceptions } \\
\hline EP 1 & $\begin{array}{l}\text { I believe the ride sharing application will not use my personal data for } 0.768 \\
\text { other transaction purposes. }\end{array}$ & 3.547 & 1.143 \\
\hline EP 2 & $\begin{array}{l}\text { The digital payment system on the ride sharing application is safe and } 0.832 \\
\text { verified. }\end{array}$ & 4.126 & 0.869 \\
\hline EP 3 & $\begin{array}{l}\text { I received the product/service that matched what I ordered on the ride } 0.719 \\
\text { sharing application. }\end{array}$ & 4.287 & 0.774 \\
\hline EP 4 & The ride sharing application responded to my complaints quickly. & 3.735 & 1.001 \\
\hline \multicolumn{4}{|c|}{ Value Co-creation } \\
\hline VC 1 & $\begin{array}{l}\text { I am willing to share my experience/suggestions on the ride sharing } 0.813 \\
\text { application service if an acquaintance asks about it. }\end{array}$ & 4.067 & 0.928 \\
\hline VC 2 & $\begin{array}{l}\text { I intend to buy products/services on the ride sharing application } 0.892 \\
\text { recommended by my acquaintances. }\end{array}$ & 3.928 & 0.944 \\
\hline VC 3 & $\begin{array}{l}\text { The experience of using the ride sharing application from my friends } \\
\text { became my consideration when I needed a similar service on the } 0.852 \\
\text { application. }\end{array}$ & 4.027 & 0.923 \\
\hline
\end{tabular}

Note: E-WOM - electronic word of mouth, EP - ethical perceptions, VC - value co-creation, SD - standard deviation. Source: Data Processed Results (2021).

Table 3 shows the results of Cronbach's Alpha, Composite Reliability, Average Variance Extracted and Heteroit-Monotrait ratio of correlations of every variable. The value of Cronbach's Alpha in all variables show $>0.7$ which means that all variable constructs are reliable. For passing validity test, AVE must be $>0.5$ and discriminant validity HTMT value must $<0.90$. So, it could be said that all variables pass validity test. 
Table 3 - Validity and Reliability Measurement

\begin{tabular}{llllllll}
\hline $\mathrm{n} / \mathrm{n}$ & Cronbach's Alpha & rho_A & \multirow{2}{*}{ CR } & AVE & HTMT & & \\
\hline Electronic Word of Mouth & 0.740 & 0.751 & 0.838 & 0.567 & - & - & - \\
Value Co-creation & 0.746 & 0.749 & 0.840 & 0.570 & 0.663 & - & - \\
Ethical Perceptions & 0.812 & 0.812 & 0.889 & 0.727 & 0.718 & 0.737 & - \\
\hline
\end{tabular}

Note: CR - composite reliability, AVE - average variance extracted, HTMT - heteroit-monotrait ratio of correlations, E-WOM - electronic word of mouth, EP - ethical perceptions.

Source: Data Processed Results (2021).

In attempt to test the hypotheses of this research, we need to see probability and critical ratio value. A hypothesis is supported if critical ratio $>1.96$ and probability value $<0.05$. For the results of hypotheses testing can be seen on Table 4 .

Table 4 - Path Coefficient, Critical Ratio and Probability of Variables

\begin{tabular}{lllll}
\hline Independent Variable & Dependent Variable & Path Coefficient & Critical Ratio (CR) & Probability (P) \\
\hline E-WOM & Value Co-creation & 0.299 & 4.199 & 0.000 \\
E-WOM & Ethical perceptions & 0.536 & 11.366 & 0.000 \\
Ethical perceptions & Value Co-creation & 0.421 & 5.858 & 0.000 \\
\hline E-WOM through ethical perceptions & Value Co-creation & 0.226 & 4.967 & 0.000 \\
\hline
\end{tabular}

Source: Data Processed Results (2021).

The results of critical ratio and probability value of the variables pass hypotheses testing based on Table 4. With the value of path coefficient in Table 4, we can construct the equations that state the relationship between the variables. The equations can be written as below:

$$
V C=0.299 e-W O M+0.421 E P
$$

This equation shows that the contribution of value co-creation is a combination of the contribution of the electronic Word of Mouth (e-WOM) which is $29.9 \%$ and ethical perception which is $42.1 \%$. These variables (e-WOM and ethical perceptions) both contribute positively to value co-creation on sharing economy platform.

$$
\mathrm{EP}=0.536 \mathrm{e}-\mathrm{WOM}
$$

The equation above shows that electronic Word of Mouth (e-WOM) gives positive effect to ethical perception (PE) by $53.6 \%$. The results of all hypotheses ( $\mathrm{H} 1$ to $\mathrm{H} 4)$ can be seen in Table 5.

Table 5 - Results of Hypotheses Testing

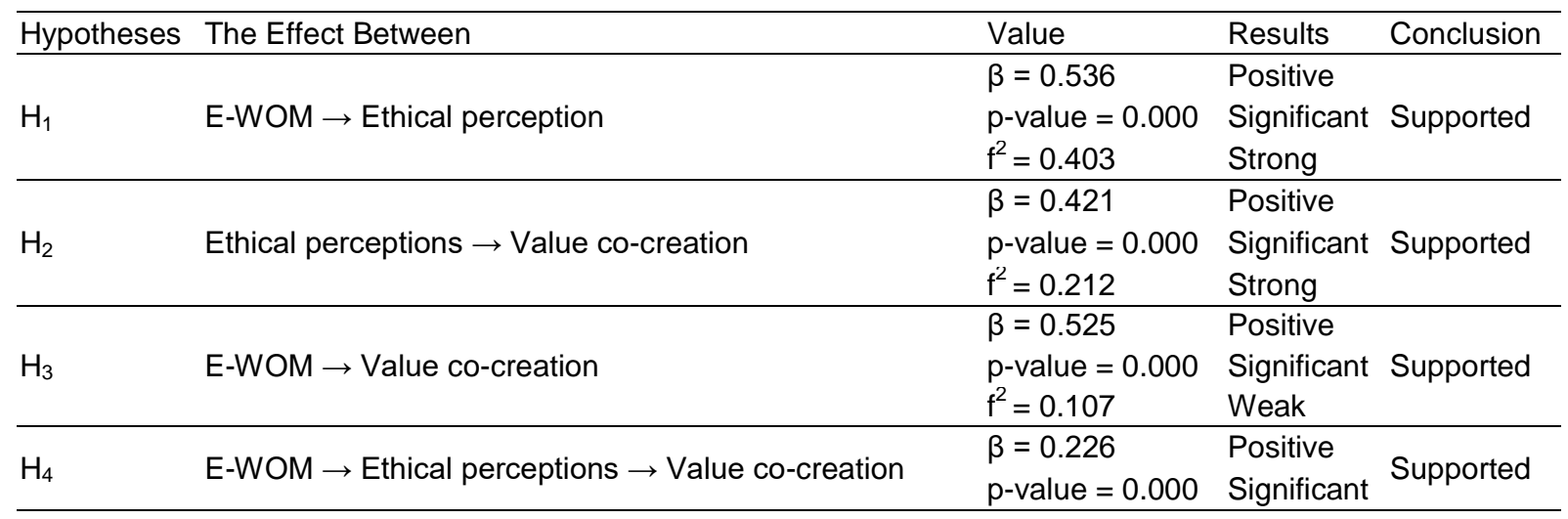

Source: Data Processed Results (2021). 
As shown in Table 5, the analysis of hypothesis $1\left(\mathrm{H}_{1}\right)$ revealed that e-WOM had a favorable effect $(\beta=0.536)$ on ethical perceptions that was statistically significant ( $p$-value $=$ $0.000)$ and strong $\left(f^{2}=0.403\right)$. The findings of this study revealed that when an individual's eWOM rises, so does the ethical perceptions of sharing economy platform users. The testing of hypothesis $2\left(\mathrm{H}_{2}\right)$ revealed that ethical perceptions had a positive influence $(\beta=0.421)$ on value co-creation that was statistically significant $(p$-value $=0.000)$ and powerful $\left(f^{2}=0.212\right)$. According to the findings, it could be stated that individual ethical perceptions influenced value co-creation on a sharing economy platform. The testing of hypothesis $3\left(\mathrm{H}_{3}\right)$ found that e-WOM had a positive influence on value co-creation $(\beta=0.525)$, which was statistically significant $\left(p\right.$-value $=0.000$ ) although weak $\left(f^{2}=0.107\right)$. This shows that the more an individual's e-WOM, the higher the individual's value co-creation toward sharing economy platform users will be. Analysis of hypothesis $4\left(\mathrm{H}_{4}\right)$ indicates that ethical perceptions can act as mediating effect between e-WOM and value co-creation which $p$-value $<0.000$ and has significant effect $(\beta=0.226)$.

Based on the results above, the explanation for hypothesis testing can be explained as follows:

1. Electronic Word of Mouth (e-WOM) has a positive effect on the creation of shared value. The results of this hypothesis are in line with the statement put forward by Diges \& Debasa (2020) which states that digital marketing, especially e-WOM, is an effective strategy in increasing loyalty from loyal customers and attracting potential customers for sharing economy platforms. The statement put forward by Diges and Debasa is based on qualitative research (Systematic Literature Review) because there is no quantitative research that states this relationship. Therefore, in this study, the results of quantitative research support the statement put forward by Diges and Debasa.

In the development of a country's economic activity, consumers especially those in big cities with dense population activities with unavoidable road congestion levels, the presence of the sharing economy platform is a smart solution for the community, especially between vehicle owners and consumers who need transportation services. With more and more users using sharing economy platform and the presence of social media can trigger electronic Word of Mouth (e-WOM) marketing quickly. The more widespread e-WOM marketing is, users who have never used sharing economy platform are increasingly convinced to use the service. The high number of requests will also increase the number of vehicle owners to become service providers in the co-creation process. This certainly increases the value of sharing economy platform company so that the company can continue to be active in providing services needed by consumers. This is in line with the explanation (Diges \& Debasa, 2020) which says that e-WOM is an effective strategy in increasing the loyalty of loyal customers and in attracting potential customers for the sharing economy platform. In testing E-WOM1 to E-WOM5 indicators, it is seen that the E-WOM2 indicator is excluded from the modeling. The statement for E-WOM2 states that "I trust the comments made by my acquaintances on social media." shows that comments on social media do not always have to be done by acquaintances to make users of the service believe. There is the possibility of comments made by Key Opinion Leaders (KOL) or testimonials from customers that make someone believe their comments on social media. Therefore, the effectiveness of e-WOM does not always come from acquaintances on social media. It can also come from expert opinions (influencers), testimonials and other things that have a good reputation in doing word of mouth marketing.

2. Electronic Word of Mouth (e-WOM) has a positive effect on ethical perceptions. Currently there is still very limited research that discusses the relationship between e-WOM and ethical perceptions in the sharing economy platform. Most of the existing research still discusses the relationship between e-WOM and purchasing decisions (Kunja \& GVRK, 2018) as well as with consumer participation (Martinez-Gonzalez et al., 2021). Therefore, this research can be regarded as a pioneer to see the relationship between e-WOM and ethical perceptions in the sharing economy platform. The results of this study indicate that electronic word of mouth (e-WOM) marketing also has a positive effect on ethical perceptions. This is understandable because consumers have started to be smart in assessing whether a service 
can be used safely or not. If you look at the conditions before the emergence of sharing economy platforms, people didn't dare to go on a trip with someone they didn't know. However, with the presence of the sharing economy platform, consumers even feel confident to travel even with strangers if it is through sharing economy platform that has trustworthy credibility. Therefore, the more active e-WOM marketing can increase the ethical perception of a service, especially if the response is positive.

With consumers increasingly free to make responses to a service through social media, the public can see how e-WOM responses made by service users are responses that can be taken into consideration. This response also reflects the ethical values adopted by the company such as privacy, data security, payment validation and security and others. If there are problems with matters related to ethics, consumers do not hesitate to make responses and publish them through social media.

3. Ethical Perception has a positive influence on the creation of shared value. The results of this study are in line with the research conducted by Nadeem et al. (2020) which states that ethical perceptions have an influence on value co-creation. Consumers will be more active in creating shared value if the services in sharing economy platform are guaranteed security such as data security issues, verified payments, service recovery, as well as compatibility between the services requested and those provided. With the better application of ethical perception of a sharing economy platform, it will encourage consumers to use sharing economy platform and will increase the number of service providers to provide their services through the application.

It is very important for companies to continuously maintain consumer trust through the application of business ethics, especially during rampant security problems in cyberspace (cyber security). With the development of technology in the internet world, of course, it can also become an easy target for hackers to act and hack the security of data owned by the company. Therefore, the company's commitment to data security, consumer complaint handling procedures and others remain the company's top priority for this sharing economy platform. In addition, companies must also ensure strict application of business ethics in the company's internal environment which can also be a big potential for data leakage due to irresponsible actions by certain individuals.

4. Electronic word of mouth has a positive influence on the creation of shared value through ethical perceptions. There has been no previous research which discusses ethical perceptions that mediate between electronic word of mouth and value co-creation. However, based on the results of the research obtained on the direct influence of variables both with and without mediation, the results show that the greater influence of e-WOM on value cocreation occurs without mediating ethical perceptions. Based on the results of this study, the authors interpret that value co-creation activities between consumers and service providers can be increased through consumer considerations if only through e-WOM marketing. However, this does not mean that the ethical perception of a company is not important. On the contrary, when consumers do e-WOM marketing, consumers have a picture of the moral standards of a company. With the presence of ethical perceptions that mediate the relationship between e-WOM and value co-creation, it is evidence that ethical factors in this sharing economy platform company are also an important consideration for consumers to use services on these applications. Therefore, this sharing economy platform company needs to encourage consumers to provide comments or feedback about the services they have used through the application so that they can lure new customers to use similar services. This in turn can also increase the company's valuation of the sharing economy platform and increase the number of service providers to take advantage of this sharing economy platform to gain customers.

\section{CONCLUSION}

The data supports all hypotheses ( $\mathrm{H} 1$ through $\mathrm{H} 4)$, according to the study's findings. As a result, it can be concluded that, while e-WOM has a positive and significant effect towards ethical perceptions $\left(\mathrm{H}_{1}\right)$ on sharing economy platform. E-WOM also has positive and 
significant impact towards value co-creation $\left(\mathrm{H}_{3}\right)$. Furthermore, ethical perceptions have a positive and significant impact on value co-creation $\left(\mathrm{H}_{2}\right)$ while using sharing economy platform. In terms of the mediation effect, ethical perception has a positive and significant impact on the use of the sharing economy platform when it comes to value co-creation $\left(\mathrm{H}_{4}\right)$. The results support previous research about the effect of ethical perceptions towards value co-creation on sharing economy platform.

There are limitations of this research that could be considered for suggestion of future research as mentioned below:

1. The variables used in this study to predict the value co-creation are only electronic Word of Mouth (e-WOM) and ethical perceptions. Therefore, for further research, it can be considered to examine other variables such as user generated content (UGC), key opinion leaders (KOL), reviews, representatives (ambassador) or other matters related to digital marketing;

2. The scope of this research is still general in nature, namely taking samples for the entire population of Indonesia. Most of the results came from Java Island, which is the largest user of the sharing economy platform because it is the most densely populated island in Indonesia. It can be considered for further research to cover certain areas in Indonesia, such as Sumatra Island only, or Sulawesi Island only, where the level of use of the sharing economy platform application is different from Java Island.

From this research, managerial implications that can be applied to company are:

1. Research shows that the effect of shared value creation is more influenced by ethical perceptions than by electronic Word of Mouth (e-WOM) marketing. Therefore, sequentially, companies need to consider aspects of ethical perception first and then focus on e-WOM marketing.

2. This study also looks at indicators of ethical perception that need to be considered by companies to increase value co-creation in their application, namely:

- Keep the digital payment system on the sharing economy platform secure and verified;

- Keep consumer personal data from being used for transaction purposes other than on the relevant sharing economy platform.

3. The electronic Word of Mouth (e-WOM) marketing indicators on the sharing economy platform to consider are:

- Increase comments/good reviews about the use of the platform so that more people are interested in using the application;

- Increase the popularity of the sharing economy platform with the increasing number of reviews/comments given.

\section{REFERENCES}

1. Aksara, D. (2021, September 21). Bisnis: Big Alpha. Retrieved from Big Alpha Website: https://bigalpha.id/news/ada-anggota-baru-ini-daftar-unicorn-indonesia-paling-update.

2. Al-Imamy, S., \& Nadeem, W. (2021). Is this real? Cocreation of value through authentic experiential augmented reality: the mediating effect of perceived ethics and customer engagement. Information Technology \& People, ahead-of-print, doi: 10.1108/ITP-072020-0455.

3. Bataineh, A. (2015). The Impact of Perceived e-WOM on Purchase Intention: The Mediating Role of Corporate Image. International Journal of Marketing Studies, doi: 10.5539/ijms.v7n1p126.

4. Belk, R. (2014). You are what you can access: Sharing and collaborative consumption online. Journal of Business Research, 67(8), 1595-1600.

5. Diges, L. P., \& Debasa, F. (2020). The Use of Digital Marketing Strategies in the Sharing Economy: A Literature Review. Journal of Spatial and Organizational Dynamics, Vol. VIII, Issue 3, 217-229.

6. Go-Jek. (2021, November 4). About Us: Gojek. Retrieved from Gojek Website: https://www.gojek.com/sg/about/ 
7. Gov, C. (2021, December 04). United States Census Bureau. Retrieved from Census Gov Web Site: https://www.census.gov/popclock/world.

8. Gronroos, C., Strandvik, T., \& Heinonen, K. (2015). Value Co-Creation: Critical Reflections. Helsinki: CERS, Hanken School of Economics.

9. Kunja, S., \& GVRK, A. (2018). Examining the effect of e-WOM on the customer purchase intention through value co-creation (VCC) in social networking sites (SNSs). Management Research Review, MRR-04-2017-0128.

10. Laczniak, G., \& Murphy, P. (2018). The role of normative marketing ethics. Journal of Business Research, 95, 401-407.

11. Martinez-Gonzalez, J. A., Parra-Lopez, E., \& Barrientos-Baez, A. (2021). Young Consumers' Intention to Participate in the Sharing Economy: An Integrated Model. Sustainability 2021, 13, 430., doi:10.3390/su13010430.

12. Mikalef, P., Giannakos, M., \& Pappas, I. (2017). Designing social commerce platforms based on consumers' intentions. Behavior and Information Technology, doi: 10.1080/0144929X.2017.1386713.

13. Nadeem, e. a. (2019). The Role of Ethical Perceptions in Consumers' Participation and Value Co-creation on Sharing Economy Platforms. Journal of Business Ethics, doi: 10.1007/s10551-019-04314-5.

14. Nadeem, W., \& Al-Imamy, S. (2020). Do ethics drive value co-creation on digital sharing economy platforms? Journal of Retailing and Consumer Services, Vol. 55, p. 102095, doi: 10.1016/j.jretconser.2020.102095.

15. Nadeem, W., Juntunen, M., Shirazi, F., \& Hajli, N. (2020). Consumers'value co-creation in sharing economy: The role of social support, consumers' ethical perceptions and relationship quality. Technological Forecasting and Social Change 151:1-13, doi: 10.1016/j.techfore.2019.119786.

16. Reinartz, W., Haenlein, M., \& Henseler, J. (2009). An empirical comparison of the efficacy of covariance-based and variance-based SEM. International Journal of Research in Marketing, 26(4), 332-344.

17. Sa'ait, N., Kanyan, A., \& Nazrin, M. F. (2016). The Effect of E-WOM on Customer Purchase Intention. International Academic Research J. of Social Science 2(1), 73-80.

18. Stephany, A. (2015). The Business of Sharing: Making it in the New Sharing Economy. London: Palgrave Macmillan.

19. Sumi, \& Tjokrosaputro, M. (2020). Pengaruh Customer Participation Dan Customer Ethical Perception Terhadap Value Co-Creation. Jurnal Manajerial dan Kewirausahaan, Volume II No. 4/2020, 1079-1085.

20. Vargo, S., Maglio, P., \& Akaka, M. A. (2008). On Value and Value Co-Creation: A Service Systems and Service Logic Perspective. European Management Journal 26(3), 145-152.

21. Wu, P. C., \& Wang, Y.-C. (2011). The influences of electronic word-of-mouth message appeal and message source credibility on brand attitude. Asia Pacific Journal of Marketing and Logistics 23(4), 448-472. 